\title{
Non-pharmacological therapies for postpartum analgesia: a systematic review
}

\author{
Terapias não farmacológicas para analgesia no pós-parto: uma revisão sistemática
}

Larissa Ramalho Dantas Varella Dutra ${ }^{1}$, Alane Macatrão Pires de Holanda Araújoํㅜ, Maria Thereza Albuquerque Barbosa Cabral Micussi

DOI 10.5935/2595-0118.20190014

\section{ABSTRACT}

BACKGROUND AND OBJECTIVES: Abdominal and pelvic pain is a prevalent condition among women in the immediate postpartum period. Non-pharmacological therapies are of great importance for the treatment of this condition since they do not cause systemic side effects, such as drowsiness, irritability, and changes in the composition of breast milk. This article aims to identify and evaluate the efficacy of non-pharmacological analgesic therapies used in the immediate puerperium in abdominal-pelvic pain.

CONTENTS: Searches were carried out in the main databases from September to October 2017 using the following descriptors "treatment" AND "pain" AND "postpartum"; "Treatment" AND "pain” AND "postpartum” AND "analgesics" AND "non-pharmacological". Controlled and randomized clinical trials published between January 2007 and August 2017, in Portuguese, English, and Spanish were included. Of the 1737 studies found in the databases, 42 were selected by the title. According to the eligibility criteria, 13 studies were included. The total sample size of the studies ranged from 21 to 266. In the intervention groups, the sample ranged from 11 to 126 women who underwent cryotherapy, transcutaneous electrical stimulation, LASER, acupuncture and ear acupressure.

CONCLUSION: Interventional practices such as transcutaneous electrical nervous stimulation and cryotherapy presented significant data relevant to the reduction of abdominal and pelvic pain. The techniques of acupuncture and ear acupressure still present inconclusive data. Despite the relief of perineal pain, laser therapy showed no statistically significant effect on pain relief when compared to the placebo group.

Keywords: Analgesics, Cesarean section, Pain, Physiotherapy.

Larissa Ramalho Dantas Varella Dutra - (1) https://orcid.org/0000-0002-5441-5557; Alane Macatráo Pires de Holanda Araújo - Dhttps://orcid.org/0000-0002-3832-8808; Maria Thereza Albuquerque Barbosa Cabral Micussi - Dhttps://orcid.org/0000-0003-4140-5568.

1. Universidade Federal do Rio Grande do Norte, Natal, RN, Brasil.

Submitted in July 09, 2018.

Accepted for publication in December 20, 2018.

Conflict of interests: none - Sponsoring sources: none

Correspondence to:

Av. Senador Salgado Filho, s/n. Campus Universitário - Lagoa Nova

59078-970 Natal, RN, Brasil.

E-mail: maria.thereza.micussi@gmail.com

(C) Sociedade Brasileira para o Estudo da Dor

\section{RESUMO}

JUSTIFICATIVA E OBJETIVOS: Dor abdominal e pélvica são condiçôes prevalentes entre as puérperas no período pós-parto. As terapias não farmacológicas nesses casos são de grande importância, tendo em vista a ausência de efeitos adversos sistêmicos, tais como sonolência, irritabilidade e modificaçôes no leite materno. O objetivo deste estudo foi identificar e avaliar a eficácia das terapias analgésicas não farmacológicas utilizadas no puerpério imediato na dor abdominal e pélvica.

CONTEÚDO: Realizou-se buscas nas principais bases de dados, no período de setembro a outubro de 2017, utilizando-se as combinaçôes: "treatment" AND "pain" AND "postpartum"; "treatment" AND "pain" AND "postpartum" AND "analgesics" AND "non-pharmacological". Foram incluídos ensaios clínicos controlados e randomizados, publicados no período de janeiro de 2007 a agosto de 2017, nos idiomas português, inglês e espanhol. Dos 1.737 estudos encontrados nas bases de dados, 42 foram selecionados pelo título. De acordo com os critérios de elegibilidade, incluiu-se 13 estudos. $\mathrm{O}$ tamanho total das amostras dos estudos variou entre 21 e 266. Nos grupos com intervençáo, a amostra variou entre 11 e 126 mulheres que foram submetidas a crioterapia, eletroestimulação elétrica nervosa transcutânea, LASER, acupuntura e auriculoterapia.

CONCLUSÂO: As práticas intervencionistas como a eletroestimulação elétrica nervosa transcutânea e a crioterapia apresentaram dados significativos relevantes na redução da dor abdominal e pélvica. As técnicas de acupuntura e auriculoterapia ainda apresentam dados inconclusivos. Apesar de provocar alívio da dor perineal, a laserterapia não mostrou efeito estatisticamente significativo para alívio da dor quando comparada com o grupo placebo.

Descritores: Analgesia, Cesariana, Dor, Fisioterapia.

\section{INTRODUCTION}

In the immediate puerperium, abdominal and pelvic pain are prevalent conditions among women ${ }^{1,2}$. A cohort study of 1,288 women who underwent cesarean section and vaginal birth ${ }^{2}$, identified a prevalence of pain of $10.9 \%$ in the first 36 hours after birth. The literature shows that women who underwent cesarean section reported 2.4 more complaints of pain compared to women undergoing vaginal birth ${ }^{3}$. Other research conducted in Brazil showed that women who had vaginal birth were $82 \%$ less likely to experience intense pain in the immediate puerperium ${ }^{4}$. Another study reveals that postpartum pain may persist for up to one year and is more common after cesarean section ${ }^{5}$. 
In the postpartum after a vaginal birth, perineal pain was observed due to an episiotomy or spontaneous perineal trauma that trigger a local inflammatory process with the presence of acute pain $^{6}$. In the cesarean section, surgical wound pain is considered the main complaint in women ${ }^{7}$, which impedes functionality in the immediate puerperium. Regardless of the mode of birth and local tissue trauma, abdominal pain may also be present in most women as a result of uterine contractions ${ }^{1}$.

The discomfort caused by painful condition relieves the quality of life, mobility, self-care, breastfeeding and eliminatory functions of puerperium ${ }^{7,8}$. Pharmacological treatment is often prescribed for analgesia, favoring patient recovery, reducing maternal distress and increasing the mother's interactions with the newborn ${ }^{8,9}$.

Despite advances in the knowledge of pathophysiology, treatment for pain and the availability of new drug systems, it is still possible to find patients who are unable to use drugs, making this therapy unfeasible ${ }^{1}$. In addition, Steen et al. ${ }^{10}$ reported that the use of drug alone has not been enough to promote analgesia in these women. It is possible to identify in the literature several non-pharmacological analgesic therapies used in acute processes of tissue trauma, discussing the low cost for application and the wide possibility of indications.

In view of the painful symptoms in distinct regions such as the abdomen and pelvis due to the parturition process, whether by vaginal birth or cesarean section, present in the first days of the puerperium, it is necessary to identify and assess the effectiveness of the non-pharmacological analgesic therapies used in this period, to better guide the clinical and scientific practice of health professionals working directly in obstetric care.

\section{CONTENTS}

This study was characterized as a systematic review, carried out in the main databases Pubmed; LILACS, Ovid EMBASE, Scielo, CAPES, IBECS, SCOPUS, SCIENCE DIRECT and CAPES thesis bank. The searches were carried out from September to
October 2017, using the following combinations: "treatment" AND "pain" AND "postpartum"; "treatment" AND "pain” AND "postpartum” AND "analgesics" AND "non-pharmacological”. Inclusion criteria were complete articles published between January 2007 and August 2017 in the Portuguese, English and Spanish languages; studies with the methodological design of randomized controlled clinical trial presenting a quantitative analysis of the outcome pain; articles that presented in the title and abstract approach of a non-pharmacological intervention for analgesia in the immediate puerperium. In cases where the title and the abstract were not enlightening, the search for the article was carried out in full to avoid the inclusion of important studies.

The articles identified by the initial search strategy were independently assessed and covered by two authors, strictly adhering to the eligibility criteria defined in the research protocol and assessed methodologically based on the PEDro ${ }^{11}$ scale. Duplication studies were excluded from the databases.

The systematic review was performed according to the guidelines of the Cochrane Reviewer's Handbook and the PRISMA guidelines $^{12}$ (Preferred Reporting Items for Systematic Reviews and Meta-Analysis). The steps of the research are demonstrated in the flowchart (Figure 1), according to the methodological procedure proposed in the study.

\section{Selection of studies}

The results of the research are shown in figure 1. Initially, 1,737 studies were found in the databases, 13 of which were selected according to the eligibility criteria.

\section{Characteristics of the studies}

The total sample size of the studies ranged from 21 to 266 with the size of the intervention group ranging from 11 to 126 women ${ }^{13,14}$. In the assessment of the methodological quality, an average score of 7 (range of 5 to 10 ) was verified, as shown in table 1. The resources found were cryotherapy ${ }^{15-18}$, TENS ${ }^{13,19-22}$, laser therapy ${ }^{23,24}$, auriculotherapy ${ }^{14}$ and acupuncture ${ }^{25}$ and are described in table 2 .

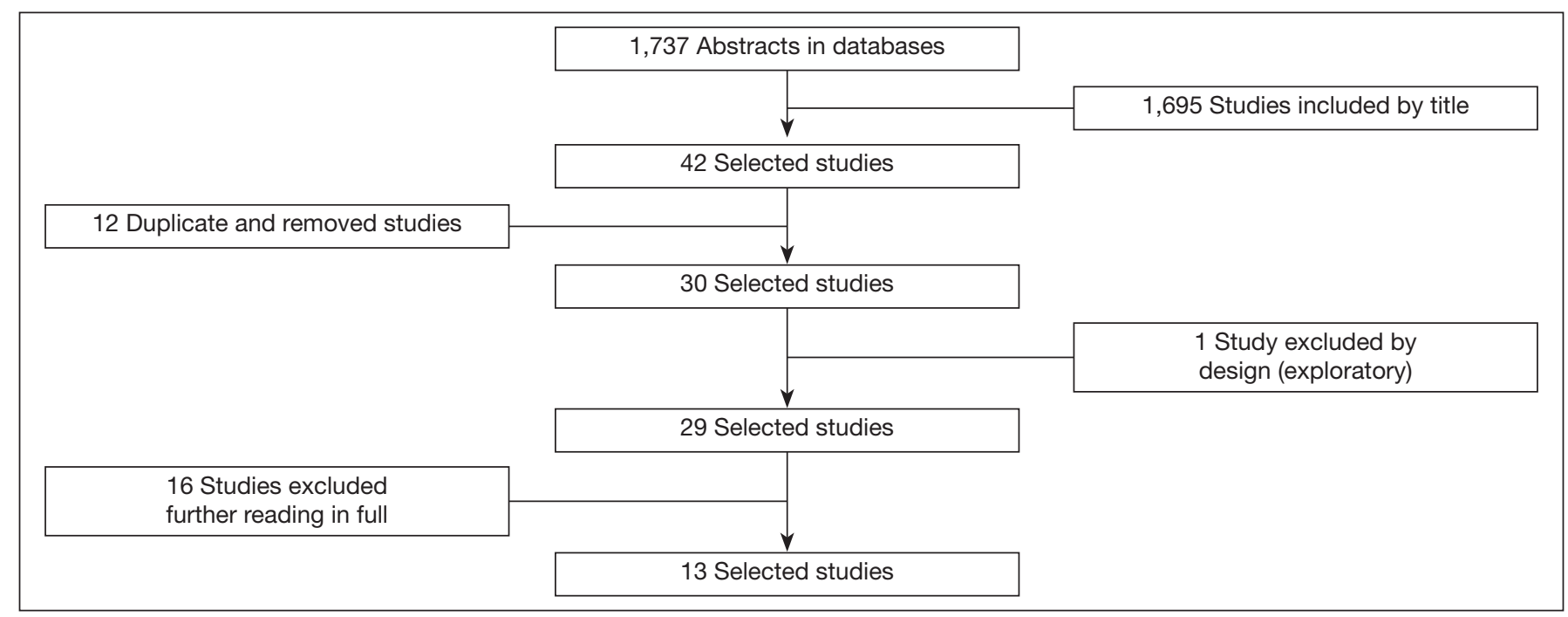

Figure 1. Flowchart of the systematic review steps recommended by PRISMA 
Table 1. Characteristics of included articles

\begin{tabular}{|c|c|c|c|}
\hline Authors & Methodological/blind design & $\begin{array}{l}\text { Non-pharmacological } \\
\text { resource used }\end{array}$ & $\begin{array}{l}\text { Methodological quality } \\
\text { (PEDro scale) }\end{array}$ \\
\hline Lu et al. ${ }^{15}$ & Quasi-randomized controlled experimental/unblinded trial & Cryotherapy & 5 \\
\hline $\begin{array}{l}\text { Kayman-Kose } \\
\text { et al. }{ }^{19}\end{array}$ & Randomized controlled/single-blind clinical trial (patient) & TENS & 8 \\
\hline Pitangui et al. ${ }^{20}$ & Randomized double-blind clinical trial & TENS & 8 \\
\hline Pitangui et al. ${ }^{21}$ & Controlled randomized/unblinded clinical trial & TENS & 8 \\
\hline Santos et al. ${ }^{24}$ & Randomized double-blind clinical trial & Low-level laser therapy & 9 \\
\hline Santos et al. ${ }^{23}$ & Pilot, randomized clinical trial & Low-level laser therapy & 9 \\
\hline Kwan and $\mathrm{Li}^{14}$ & Randomized controlled/double-blind trial & Auriculotherapy & 10 \\
\hline Morais et al. ${ }^{18}$ & Randomized controlled/double-blind clinical trial & Cryotherapy & 9 \\
\hline
\end{tabular}

TENS = transcutaneous electrical nerve stimulation.

Table 2. Non-pharmacological analgesic resources for abdominal-pelvic pain relief in the immediate puerperium

\begin{tabular}{|c|c|c|c|c|c|}
\hline Authors & $\begin{array}{l}\text { Objective of } \\
\text { the study } / \mathrm{n}= \\
\text { sample }\end{array}$ & Intervention groups & Intervention & Assessment tools & $\begin{array}{l}\text { Effectiveness of the inter- } \\
\text { vention }(p<0.05) \text { * }\end{array}$ \\
\hline
\end{tabular}

Cryotherapy

Lu et al. ${ }^{15}$ To assess the The study was per- The IG underwent the For both groups, the pain effect of a cold formed with two application of ice pack was measured in 4 mocompress on groups containing 35 in the perineal region ments through BPI: $4 \mathrm{~h}$ e pisiotomy women in each. pain reduction/ $\mathrm{n}=70$.

Oliveira et al. ${ }^{16}$

\footnotetext{
To compare The research was
} compare The research was Single application of ice the effect of done with three pack in the perineal reapplying ice groups containing gion at $-10^{\circ} \mathrm{C}$ between 2 pack for 10,38 patients each: and 56 hours postpar15 and 20 min- Group underwent tum after vaginal birth, in utes in the per- 10 min interven- women with pain $\geq 3$ asineal region in tion with ice packs; sessed by visual analog pain reduction/ Group underwent scale (VAS). $\mathrm{n}=114$. 15 min intervention with ice packs. Control group underwent $20 \mathrm{~min}$ of ice.
BPI: significant reduction of pain $48 \mathrm{~h}$ after birth in the intervention group $(p=0.002)$. from 12 to $15^{\circ} \mathrm{C}$, lasting intervention), 12,24 and from 15 to 20 minutes $48 \mathrm{~h}$ after birth. It was and encouraged to perform ice pack as many times as possible in the first 4 hours postpartum. For the next three days, they should use at least 3 times a day. All IG and CG participants received routine care, consisting of nonsteroidal anti-inflammatory and hot-seat baths after 24 hours baths after

also assessed the interference of pain in the $A D L$, through a questionnaire developed for the research.

DA questionnaire: significant reduction of pain interference on daily activities $(p=0.001)$.

The pain was measured in 4 moments through the VAS: before, immediately after, 20 minutes and 40 minutes after the intervention.

The three groups presented significant pain reduction $(p=0.001)$, with no statistical difference between them $(p=0.066)$. Application of 10 minutes and 15 minutes of ice pack has the same benefits in reducing pain like that of 20 minutes. 
Table 2. Non-pharmacological analgesic resources for abdominal-pelvic pain relief in the immediate puerperium - continuation

\begin{tabular}{lllll}
\hline Authors & $\begin{array}{l}\text { Objective of } \\
\text { the study } / \mathrm{n}= \\
\text { sample }\end{array}$ & Intervention groups Intervention & Assessment tools & $\begin{array}{l}\text { Effectiveness of the inter- } \\
\text { vention }(p<0.05){ }^{*}\end{array}$
\end{tabular}

Cryotherapy

Leventhal To assess the Participants included et al. ${ }^{17}$ effectiveness nulliparous women of an ice pack divided into 3 groups applied for 20 ( $n=38$ per group): minutes to relieve perineal pain after spontaneous vaginal birth/ $n=114$.

Experimental group underwent intervention with ice pack in the perineum; Placebo group underwent intervention with water packs at room temperature; Control group without intervention.

Morais et To assess the The volunteers were al. ${ }^{18} \quad$ clinical effec- divided into 2 groups tiveness of containing 40 volcryotherapy unteers in each: to control pain $\mathrm{E} \times \mathrm{p}$ e $\mathrm{r} \mathrm{i} \mathrm{m}$ e $\mathrm{n}$ and perineal tal group underedema after went cryotherapy; humanized Group without cryovaginal birth / therapy. $\mathrm{n}=80$
The packages were applied in a single instance for 20 minutes in the perineal region, between 2 and 48 hours postpartum. The package consisted of a plastic bag $8 \mathrm{~cm}$ wide by $16 \mathrm{~cm}$ long, filled with $250 \mathrm{~mL}$ of water. For the experimental group, the pack was placed in the freezer and removed as ice for the intervention. The ice and water packs were wrapped in $20 \times 20$ $\mathrm{cm}$ fine cotton fabric to avoid direct contact with the perineum.

The experimental group underwent 6 applications of ice pack crushed in the perineum region, for 20 minutes, reducing the temperature between 10 and $15^{\circ} \mathrm{C}$, with $60 \mathrm{~min}-$ utes between the applications. The group without cryotherapy received a water pack, which did not reduce the temperature at that level, respecting the same protocol of application of the experimental group.
The data were collected daily by 4 evaluators between 11:00 and 15:00. They were collected in the following sequence: interview, initial assessment of perineal pain, randomization, body temperature measurement, and perineal trauma length measured by the use of Perirule $^{\mathrm{TM}}$. A numerical scale (zero to 10) was used for the assessment of pain.

The use of an ice pack in the perineum is useful in the treatment of perineal pain after vaginal birth. A comparison of mean pain at baseline and after 20 minutes showed significant pain reduction $(p<0.001)$ in the 3 groups and the experimental group had a lower average pain score compared to the control group $(p=0.032)$

They were assessed: perineal pain and perineal edema with assessments performed immediately before and at the end of each application in each group to determine the immediate effects of the therapy and were reassessed at 24 hours postpartum to verify the late effects of cryotherapy. The combined pain assessment scale (CSAP) was used to assess pain level.
There was no significant difference for perineal pain and edema scores between groups with or without cryotherapy up to 24 hours after birth. There was no difference between groups when repeated measures were analyzed in all assessments, considering the median pain scores $(p=0.3)$ and perineal edema $(p=0.9)$. Perineal cryotherapy did not influence the amount of analgesics used $(p=0.07)$ and no adverse effects were recorded.

\section{TENS}

KaymanKose et al. ${ }^{19}$
To assess the Participants efficiency and randomized reliability of four TENS in the Cesarean treatment of group uterine pain intervention and surgical TENS switched incision after Cesarean birth $/ \mathrm{n}=200$.$$
\text { then }
$$
went roup und Vaginal birth group plication were reported. underwent inter- For vaginal birth patients, vention with TENS the electrodes were poswitched off; sitioned in the region of Group of vaginal birth the lower abdomen corunderwent interven- responding to the fundus tion. were All participants in the interinto vention groups received groups: the application of TENS section immediately after birth. underwent $A$ frequency of $100 \mathrm{~Hz}$ with and intensity according off; to the patient's sensitivity sec- were used for the intervention groups. No pulse of the uterus. For those who underwent a cesarean section, the electrodes were positioned above and below the OW.
Pain was assessed before TENS is effective for and immediately after ap- uterine pain relief and plication through VAS and operative wound. Pain VNS. reduction was significant for the groups that underwent TENS intervention. For cesarean section: VAS and visual numerical scale (VNS) $\quad(p<0.001)$. For vaginal birth: VAS $(p=0.022)$ and VNS $(p=0.005)$. 
Table 2. Non-pharmacological analgesic resources for abdominal-pelvic pain relief in the immediate puerperium - continuation

\begin{tabular}{|c|c|c|c|}
\hline Authors & $\begin{array}{l}\text { Objective of } \\
\text { the study } / \mathrm{n}= \\
\text { sample }\end{array}$ & Intervention groups & Intervention \\
\hline \multicolumn{4}{|l|}{ TENS } \\
\hline $\begin{array}{l}\text { Pitangui } \\
\text { et al. }{ }^{20}\end{array}$ & $\begin{array}{l}\text { To assess the } \\
\text { effectiveness } \\
\text { of low-inten- } \\
\text { sity TENS and } \\
\text { high-intensity } \\
\text { TENS in episi- } \\
\text { otomy pain re- } \\
\text { duction } / n=33 \text {. }\end{array}$ & $\begin{array}{l}\text { The volunteers } \\
\text { were randomized } \\
\text { into three groups: } \\
\text { Group runder- } \\
\text { went intervention } \\
\text { with TENS of } 5 \mathrm{~Hz} \text {; } \\
\text { Group underwent } \\
\text { intervention with } \\
\text { TENS of } 100 \mathrm{~Hz} \text {; } \\
\text { Placebo group on in- } \\
\text { tervention with the de- } \\
\text { vice switched off. }\end{array}$ & $\begin{array}{l}\text { The intervention was per- } \\
\text { formed for all groups be- } \\
\text { tween } 6 \text { and } 24 \text { hours } \\
\text { postpartum with the elec- } \\
\text { trodes in parallel, close to } \\
\text { the episiotomy, following } \\
\text { a pudendal and femoral } \\
\text { nerve region. The intensi- } \\
\text { ty of the device was pro- } \\
\text { grammed according to the } \\
\text { sensitivity of the patient, } \\
\text { and the pulse width was } \\
100 \mu \text { s. The intervention } \\
\text { lasted } 30 \text { minutes. }\end{array}$ \\
\hline
\end{tabular}

Olsen et To compare the Participants were The intervention was peral. ${ }^{13}$ effects of low and high-intensity high-frequency TENS in reducing abdominal pain caused by uterine contractions during breastfeeding $/ \mathrm{n}=21$.

randomized into two groups:

Group underwent intervention with TENS using intensity less than $50 \mathrm{~mA}$ performed in 13 volunteers; Group underwent intervention with TENS using intensity of 10 to $15 \mathrm{~mA}$ in eight volunteers.

Pitangui et al..$^{21}$

To assess the effectiveness of high-frequency TENS as a pain relief resource for postpartum women with episiotomy/ $n=40$.

The volunteers were randomized two groups with 20 participants each: Group underwent intervention with TENS with high frequency; The group without intervention.

Lima et To assess the The patients were al. 22 analgesic effect of TENS modulation in high $(100 \mathrm{~Hz})$ and low $(4 \mathrm{~Hz})$ frequency in post-cesarean section pain $/ \mathrm{n}=34$. randomly assigned, in three treatment groups: G100: underwent TENS of $100 \mathrm{~Hz}$ G4: underwent TENS of $4 \mathrm{~Hz}$; GP: placebo group underwent TENS switched off.
Assessment tools

Effectiveness of the intervention $(p<0.05)$ *

\begin{abstract}
The pain was assessed TENS of low and high inthrough the NRS before tensity are effective in the intervention, post-in- reducing perineal pain aftervention, 30 minutes ter episiotomy in the first post-intervention and 6024 hours postpartum. minutes post-intervention. Significant reduction of pain between intervention and placebo groups immediately after resting $(p=0.046)$ and sitting (0.008). Significant reduction in pain between intervention and placebo groups at rest after 30 ' $(p=0.001)$ and after 60 ' $(p=0.001)$.
\end{abstract}

High-intensity high-frequency TENS had a better outcome in reducing pain. The high-intensity group presented a pain decline of $49(\mathrm{Cl}=66.5-33.2)$, and the low-intensity group had a decline of $21(\mathrm{Cl}=39.0$ - 20.0)

The assessment of the pain was done through VAS before and after the application of TENS.
The device has been programmed for a frequency of 70 to $100 \mathrm{~Hz}$ and a pulse width of $0.2 \mathrm{~ms}$. For the high-intensity group, the application was performed for 1 'and repeated if there was still a report of pain. For the low-intensity group, the time of therapy was not reported.

All were between 6 and 24 The pain was assessed hours after a vaginal birth through NRS before iniand had a mediolateral episiotomy.

The participants were placed in dorsal decubitus position and remained in rest throughout the experiment so that there were no intercurrences that interfered In the results. TENS was applied by medium of two channels with 4 siliconized rubber electrodes $(5 \times 3 \mathrm{~cm})$ for individual use located $1 \mathrm{~cm}$ above and below the surgical incision, a pulse duration of $100 \mu$ s and intensity according to the sensorial threshold of each patient. The total TENS application time was 30 minutes and performed in a single session. tiating the intervention, 60 minutes post-intervention and $120 \mathrm{~min}-$ utes post-intervention. $M P Q$ and $P R I$ were also used at baseline and 60 minutes after the current.

The high-frequency TENS showed good results in the reduction of perineal pain in the postpartum period with episiotomy. For MPQ, PRI and NRS assessment, a significant decrease $(p<0.001)$ in the scores in the intervention group. Pain intensity was as- The results demonstrated
sessed by NRS before, a significant decrease of immediately after and at the NRS in the G100 only 20 -minute intervals $(20$, in relation to the pre-treat40 and $\left.60^{\prime}\right)$ after the elec- ment condition $(p<0.05)$. In trostimulation period. the post-treatment interThe initial assessment vals, the G100 presented was performed respecting a significant decrease in a minimum interval of 8 pain during all the interhours postpartum to avoid vals $(p<0.05)$. G4 showed acute interferences of pos- a significant decrease only tanesthetic recovery. in the 40 'and 60' intervals; and GP, only in the range of 60 ' $(p<0.05)$. TENS modulation at a high pulse rate had a greater analgesic effect than low-frequency TENS in post-cesarean section, postpartum women. 
Table 2. Non-pharmacological analgesic resources for abdominal-pelvic pain relief in the immediate puerperium - continuation

\begin{tabular}{|c|c|c|c|c|c|}
\hline Authors & $\begin{array}{l}\text { Objective of } \\
\text { the study } / \mathrm{n}= \\
\text { sample }\end{array}$ & Intervention groups & Intervention & Assessment tools & $\begin{array}{l}\text { Effectiveness of the inter- } \\
\text { vention }(p<0.05)^{*}\end{array}$ \\
\hline \multicolumn{6}{|l|}{ LASER } \\
\hline $\begin{array}{l}\text { Santos } \\
\text { et al. }{ }^{24}\end{array}$ & $\begin{array}{l}\text { To assess the } \\
\text { efficiency of } \\
\text { Low-intensi- } \\
\text { ty laser in the } \\
\text { treatment of } \\
\text { perineal pain } \\
\text { after episioto- } \\
\text { my }(n=114) \text {. }\end{array}$ & $\begin{array}{l}\text { Participants } r \text { were } \\
\text { randomized into } \\
\text { three groups with } 38 \\
\text { participants each: } \\
\text { Group underwent } \\
\text { intervention with } \\
\text { LASER of } 780 \mathrm{~nm} \\
\text { of wavelength; } \\
\text { Group undergo- } \\
\text { ing laser interven- } \\
\text { tion with } 660 \mathrm{~nm} \\
\text { of wavelength; } \\
\text { Group underwent }\end{array}$ & $\begin{array}{l}\text { All volunteers were in the } \\
\text { range of } 6 \text { to } 56 \text { hours af- } \\
\text { ter vaginal birth with me- } \\
\text { diolateral episiotomy and } \\
\text { had pain greater than } \\
3 \text { on VAS. The device } \\
\text { used in the volunteers } \\
\text { underwent the interven- } \\
\text { tion was programmed } \\
\text { at a dose of } 8.8 \mathrm{~J} / \mathrm{cm} 2 \text {, a } \\
\text { spot of } 0.04 \mathrm{~cm} 2 \text {, pow- } \\
\text { er of } 35 \mathrm{~mW} \text {, energy per } \\
\text { point of } 0.35 \text { and applied }\end{array}$ & $\begin{array}{l}\text { The pain was assessed } \\
\text { before, immediately after } \\
3 \text { and } 30 \text { minutes after } \\
\text { the application through } \\
\text { VAS. }\end{array}$ & $\begin{array}{l}\text { The low-intensity la- } \\
\text { ser was not efficient } \\
\text { in mediolateral episi- } \\
\text { otomy pain reduction. } \\
\text { There was a reduction } \\
\text { in pain in the interven- } \\
\text { tion groups } 30 \text { and } 60 \\
\text { minutes after LASER } \\
\text { application, but when } \\
\text { compared to placebo, no } \\
\text { difference was observed } \\
\text { ( } p=0.234 \text { and } p=0.111 \text {, } \\
\text { respectively). }\end{array}$ \\
\hline
\end{tabular}

Santos To assess Participants were All underwent vaginal et al. ${ }^{23}$ the effects of randomized into birth with mediolateral Low-intensity two groups with 26 episiotomy. The LASER laser therapy participants each: application was perfor perineal LASER interven- formed in three moments: pain and heal- tion group with up to 2 hours after birth, ing after episi- 660nm wavelength; between 20 and 24 hours otomy / $n=52$. Group underwent after birth and between intervention with LA- 40 and 48 hours postSER switched off; partum. The device used in the volunteers underwent the intervention was programmed for a dose of $3.8 \mathrm{~J} / \mathrm{cm} 2$, a spot of $0.04 \mathrm{~mW}$, a spot of 0,04 $\mathrm{cm} 2$, the power of $15 \mathrm{~mW}$ energy per point of 0.15 and applied punctually in the episiotomy for 10 seconds per application point.

\begin{tabular}{|c|c|c|c|c|c|}
\hline \multicolumn{6}{|c|}{ Auriculotherapy and Acupuncture } \\
\hline $\begin{array}{l}\text { Kwan } \\
\text { and } \mathrm{Li}^{14}\end{array}$ & $\begin{array}{l}\text { To assess the } \\
\text { effects of auri- } \\
\text { cle pressure in } \\
\text { reducing acute } \\
\text { perineal pain } \\
\text { in the first } 48 \\
\text { hours postpar- } \\
\text { tum / } n=266 \text {. }\end{array}$ & $\begin{array}{l}\text { Participants were } \\
\text { randomized into two } \\
\text { groups: } \\
\text { Intervention group with } \\
126 \text { women; } \\
\text { Group without in- } \\
\text { tervention with } 130 \\
\text { women. }\end{array}$ & $\begin{array}{l}\text { Participants could } \\
\text { take pain medication } \\
\text { (500mg paracetamol/4 } \\
\text { hours if necessary. } \\
\text { In the two groups, the fol- } \\
\text { lowing stimulation points } \\
\text { were chosen: "Apex of } \\
\text { the auricle, Anus, ex- } \\
\text { ternal genital organs, } \\
\text { Shenmen." The volun- } \\
\text { teers should press the } \\
\text { points for } 30 \text { ", 1x / 4h. } \\
\text { In the intervention group, } \\
\text { a seed adhesive was } \\
\text { used while in the control } \\
\text { group a seedless adhe- } \\
\text { sive was used. }\end{array}$ & $\begin{array}{l}\text { The pain was assessed } \\
\text { through VDPS and VAS: } \\
12,24 \text { and } 36 \text { h after } \\
\text { birth. Also, the average } \\
\text { consumption of parac- } \\
\text { etamol was analyzed. }\end{array}$ & $\begin{array}{l}\text { Apparently, there are no } \\
\text { positive results regarding } \\
\text { the use of auricle pres- } \\
\text { sure. } \\
\text { No difference in pain was } \\
\text { observed through AVA } \\
\text { in the first two assess- } \\
\text { ments ( } p=0.11 \text {, } p=0.30 \text {, } \\
\text { respectively). In the third } \\
\text { assessment, there was } \\
\text { pain difference between } \\
\text { the groups ( } p=0.02 \text { ). } \\
\text { In the analysis of pain } \\
\text { through VDPS no dif- } \\
\text { ference was observed } \\
\text { between the groups at } \\
\text { any time ( } p=0.49 \text {, } p= \\
0.27, p=0.06 \text { ). As for } \\
\text { paracetamol consump- } \\
\text { tion ( } p=0.13 \text {, } p=0.42 \text {, } \\
p=0.37) \text {. }\end{array}$ \\
\hline
\end{tabular}

The pain assessment was LASER did not reduce done through VAS before pain in the episiotomy. and after each session. Up to $2 \mathrm{~h}$ after birth: $\mathrm{p}=0.999$

Between 20 and 24 hours postpartum: $\quad p=0.758$ Between 40 and 48 hours postpartum: $p=0.662$. 
Table 2. Non-pharmacological analgesic resources for abdominal-pelvic pain relief in the immediate puerperium - continuation

\begin{tabular}{|c|c|c|c|c|c|}
\hline Authors & $\begin{array}{l}\text { Objective of } \\
\text { the study / } \mathrm{n}= \\
\text { sample }\end{array}$ & Intervention groups & Intervention & Assessment tools & $\begin{array}{l}\text { Effectiveness of the inter- } \\
\text { vention }(p<0.05) \text { * }\end{array}$ \\
\hline \multicolumn{6}{|c|}{ Auriculotherapy and Acupuncture } \\
\hline $\begin{array}{l}\text { Marra et } \\
\text { al. }{ }^{25}\end{array}$ & $\begin{array}{l}\text { To assess the } \\
\text { effectiveness } \\
\text { of acupunc- } \\
\text { ture in relieving } \\
\text { perineal pain } \\
\text { after mediolat- } \\
\text { eral episiotomy } \\
\text { during birth/ } \\
n=42\end{array}$ & $\begin{array}{l}\text { The patients were } \\
\text { divided into } 2 \text { equal } \\
\text { groups with } 21 \\
\text { volunteers } \\
\text { Intervention group } \\
\text { underwent } \\
\text { puncture treatment; } \\
\text { Group without inter- } \\
\text { vention that was not } \\
\text { treated with acupunc- } \\
\text { ture. }\end{array}$ & $\begin{array}{l}\text { The intervention con- } \\
\text { sisted of wrist-ankle } \\
\text { acupuncture by insert- } \\
\text { ing a needle in the right } \\
\text { ankle. The needles were } \\
\text { inserted within } 2 \text { hours } \\
\text { after birth by an acu- } \\
\text { puncturist physician in } \\
21 \text { patients. The group } \\
\text { without intervention } \\
\text { was monitored during } \\
\text { the hospitalization and } \\
\text { oral analgesic request. } \\
\text { For additional pain relief, } \\
\text { volunteers could request } \\
\text { oral medication at any time } \\
\text { during hospitalization. }\end{array}$ & $\begin{array}{l}\text { Acupuncture was con- } \\
\text { sidered ineffective when } \\
\text { women treated with nee- } \\
\text { dles required one or more } \\
\text { oral analgesics during } \\
\text { hospitalization (data were } \\
\text { extracted from the medical } \\
\text { records by the acupunctur- } \\
\text { ist). }\end{array}$ & $\begin{array}{l}\text { Wrist-ankle acupuncture } \\
\text { is a simple and effective } \\
\text { method to reduce pain } \\
\text { referred by episiotomy } \\
\text { after birth. Requests for } \\
\text { oral analgesics were sig- } \\
\text { nificantly more frequent in } \\
\text { the control group }(p<0.01) \text {. }\end{array}$ \\
\hline
\end{tabular}

${ }^{*} \mathrm{p}<0.05$ accepted as significant. IG = Intervention Group; CG = Control Group. BPI = Brief Pain Inventory; ADL: activities of daily living; VAS = visual analog scale; CSAP = combined scale to assess pain that integrates VAS, face pain scale, categorical scale and numerical scale, and ranges from zero to 10 , with zero indicating total absence of pain and 10 indicating extreme pain that can be felt. OW = operative wound; VNS = verbal numeric scale of pain; NRS = numeric rating scale; $M P Q=$ McGill Pain Questionnaire; PRI = Pain Rating Index; VDPS = Verbal Descriptive Pain Scale (no pain, mild pain, moderate pain, severe pain). Cl = confidence interval.

\section{Non-pharmacological resource}

1) Transcutaneous electrical nerve stimulation - TENS

Of the studies found, five (38.4\%) treated TENS as an effective therapy for the abdominal and pelvic pain relief in postpartum women ${ }^{13,19-22}$. Of these, three analyzed abdominal pain, and post-cesarean section wound ${ }^{13,19,22}$ and two in an episiotomy region $^{20,21}$.

Two of these studies assessed the effectiveness of TENS at high frequency ${ }^{19,21}$. One ${ }^{13}$ also assessed the high frequency comparing different intensities. The other two studies ${ }^{20,22}$ compared the effectiveness of high and low frequency for pain reduction. Table 2 shows the protocols used in each study. From these studies it is evidenced that the TENS presents a satisfactory result in the control of the pain in postpartum women, being the two intensities able to produce benefits in the reduction of the painful condition.

It is possible to find described in the literature different types of TENS, for example conventional, burst, acupuncture, and brief-intense. According to the frequency, high $(10$ to $200 \mathrm{~Hz})$, or low $(2$ to $4 \mathrm{~Hz})$, its application is indicated for acute and chronic pain, respectively ${ }^{26}$.

The use of high-frequency TENS is based on the pain gate theory proposed by Melzack and Wall in $1965^{27}$. This theory explains that the electrical stimulus emitted by the device causes excitation of the $A \beta$-afferent nerve fibers in the posterior horn of the spinal cord and it rapidly inhibits the transmissions of painful impulses by the nerve conductors of pain through the spinal cord. Therefore, its indication for the management of acute and postoperative pain may be justified, as the higher the intensity of the TENS current, the more units of receptor fibers will be recruited. In turn, the use of low-frequency TENS acts on the stimulation of the release of endogenous opioids by the brain to promote the analgesic effect. In this case, it is more recommended for chronic painful condition ${ }^{28}$.

In the literature can be found a study comparing the application of TENS in the immediate postoperative period of gynecological surgery with the use of opioids. In this study ${ }^{29}$, women were randomly divided into two groups, in which they underwent pain reduction intervention after surgery. One group received high-frequency TENS and the other group, opioids. Both groups presented satisfactory pain relief results $(p<0.001)$, indicating that non-pharmacological therapy is an excellent alternative for these patients, minimizing the adverse and systemic effects of pharmacological resources.

\section{2) Laser therapy}

Two studies (15.5\%) investigated low-level laser therapy (LLLT) for analgesia in an episiotomy region in postpartum women. In the intragroup assessment, a statistical difference was found before and after the intervention. However, no difference was found in the comparison between the intervention group and placebo $^{23,24}$.

It is possible that this difference in results occurred due to the protocols used in the studies in question. The first published study ${ }^{24}$ was a pilot used as the basis for the second article ${ }^{23}$. Santos et al. ${ }^{24}$ presented results that did not provide accurate information on the effect of LLLT on episiotomy using parameters with a wavelength of $660 \mathrm{~nm}$, a dose of $3.8 \mathrm{~J} / \mathrm{cm}^{2}$ in three sessions with a range of 20 to 24 hours between them. The authors concluded that the effect might not have occurred due to the application of laser therapy since the control group also presented significant results. Subsequently, one more group was added to the study using a dosage of $8.8 \mathrm{~J} / \mathrm{cm}^{2}$; the groups with different wavelengths $(660 \mathrm{~nm}$ and $780 \mathrm{~nm})$ were compared to the placebo 
group $^{21}$. The authors identified that regardless of wavelength applied the primary outcome was not different between the groups. It is believed that the result can be justified by the natural process of tissue recovery favoring the improvement of phlogistic signs/ pain, as well as by the Hawthorne phenomenon, in which there is a change in the patient's perception due to the special attention given by the team at the time of research ${ }^{23,24}$.

Despite the statistically insignificant results of laser therapy in the reduction of pain in perineal trauma of postpartum women presented by the studies ${ }^{23,24}$, there is an article ${ }^{29}$ that already shows promising results, indicating the effectiveness of laser therapy in perineal recovery and reduction of acute pain. An experimental study $y^{30}$ demonstrated the analgesic effect after the application of laser therapy. The application of LLLT is expected to promote changes in cell membrane permeability, wound healing, muscle relaxation, immune system modulation, and nerve regeneration. In addition, it is also expected that in the intracellular environment a state of cellular hyperpolarization occurs that may inhibit the transmission of painful stimuli to the central nervous system ${ }^{31}$. As a consequence of the change of polarity added to the release of histamine, serotonin, bradykinin and prostaglandins, there will be a reduction of the inflammatory process and pain relief ${ }^{32}$. For such effects to occur, wavelengths between 600 and 1000nm have been suggested and powers of $1 \mathrm{~mW}$ to $5 \mathrm{~W} / \mathrm{cm}^{2}$. The authors also emphasize that very low $\left(2.5 \mathrm{~W} / \mathrm{cm}^{2}\right)$ or very high $(25$ $\mathrm{W} / \mathrm{cm}^{2}$ ) potencies can cause inverse effects ${ }^{33}$.

Few studies address LLLT in the immediate puerperium phase with the aim of analgesia. Thus, it is prudent to suggest new studies with different wavelengths, time and duration of application, dose and potency, before establishing any guidelines on the effectiveness of LASER in the treatment of pain in the region of episiotomy in postpartum women.

\section{3) Cryotherapy}

Of the studies on analgesic resources for postpartum women, four $(30.7 \%)$ investigated the use of cryotherapy for the perineal pain relief after vaginal birth. Of these, three ${ }^{15-18}$ presented statistically significant results of the analgesic effect whereas only one showed the non-effectiveness of the use of ice for the pain relief in postpartum women ${ }^{18}$.

The divergence of the result found by Morais et al.18 in relation to the other studies is explained throughout the study. The authors emphasized that initially, the patients presented very low levels of pain due to the absence of tissue injury, which may have interfered in the final statistical result. The other studies ${ }^{15-17}$ assessed patients who presented some degree of perineal lesion and, consequently, developed an inflammatory picture, generating initially greater pain scores.

The application of cryotherapy varied among the studies. Three used ice pack ${ }^{16-18}$, and one applied ice packs with temperature ranging between $12^{\circ} \mathrm{C}$ and $15^{\circ} \mathrm{C}^{15}$. All articles applied cryotherapy in the perineal region. Regarding the time of therapy, three ${ }^{15,17,18}$ studies used 20 minutes of application and one ${ }^{16}$ compared different times: 10 , $15^{\prime}$ and $20^{\prime}$. Oliveira et al..$^{16}$ identified that there was no difference in the effects caused by cryotherapy with the time of application of $10^{\prime}, 15^{\prime}$ and $20^{\prime}$, that is, from the $10^{\prime}$ of application, the effect was the same for the three groups. However, it is understood that the 20 ' time is well established in the literature, bringing the expected benefits of cryotherapy over perineal pain ${ }^{15,17,18}$.

Regarding the frequency of application, in the studies by Lu et al. ${ }^{15}$ and Morais et al. ${ }^{18}$ participants were encouraged to apply compresses at least 3 times a day. The objective of these studies was to investigate the long-term effect, and there are divergences between the results, unlike the studies by Leventhal et al. ${ }^{17}$ and Oliveira et al. ${ }^{16}$ that investigated the immediate effect and found significant results for pain relief after the achievement of a single application. Similar to the study by Morais et al. ${ }^{18}$, Lu et al. ${ }^{15}$ also assessed the patient 24 hours after birth and found no significant reduction of pain at that time, however, they demonstrated a good result $48 \mathrm{~h}$ after birth. It is known that in the first hours after the tissue injury the inflammatory process is higher, causing an increase in local metabolism, the release of inflammatory factors and a greater painful condition ${ }^{16}$. In this context, despite decreasing the local metabolism, it is believed that the single application of cryotherapy, is not able to decrease the pain after 24 hours of birth. However, the use of several compresses in the first few hours postpartum ${ }^{15,18}$ may lead to an increase in the patient's pain threshold due to a decrease in metabolism and a decrease in the sensitivity of nerve endings $\mathrm{s}^{34}$, a fact that justifies long-term analgesia (48 hours).

According to the review performed by Malanga, Yan and Stark ${ }^{35}$, cryotherapy acts in the reduction of pain after injury by several mechanisms of action. Initially, it promotes a decrease in the local temperature, provokes the sympathetic reflex of vasoconstriction with consequent diminution of the local circulation that culminates with the reduction of the inflammatory agents and reduction of the secondary hypoxia. The local temperature reduction also causes localized anesthesia through a neuropraxia induced by a decrease in the activation threshold of the nociceptors and a decrease in the conduction velocity of the pain signal; a good result of cryotherapy for postoperative.

Based on the data described, it is evident that cryotherapy provides good results in the momentary relief of perineal pain in the immediate postpartum period and is, therefore, a good resource to be used in the treatment of puerperal pain. It is still important to note that the compresses should be made for approximately 20 minutes and repeated times throughout the day, given their local physiological effect.

\section{4) Acupuncture and Auriculotherapy}

Two studies (15.3\%) analyzed the effects of Chinese medicine techniques, acupuncture ${ }^{23}$, and auriculotherapy ${ }^{12}$ on reducing pain in postpartum women.

According to the review by Murakami, Fox and Dijkers ${ }^{36}$ auriculotherapy has shown good immediate results in reducing pain, has few adverse effects, is quick and easy to apply, and is a lowcost therapy that must, therefore, be stimulated for use and research by health professionals.

In the study of Kwan and $\mathrm{Li}^{14}$, after an adjusted analysis of the data, a significant result of auriculotherapy was observed in the reduction of pain $36 \mathrm{~h}$ postpartum, but there was no reduction after 12 and $24 \mathrm{~h}$. The study data are not conclusive about the effectiveness of auriculotherapy in the treatment of pain. No 
statistical difference was found regarding paracetamol consumption and pain analysis through the Verbal Descriptive Pain Scale (VPDS) in the placebo and intervention groups. Thus, more studies on the application of auriculotherapy to postpartum women are recommended.

Auriculotherapy is a method of treatment of physical and psychosomatic dysfunctions that acts by stimulating specific points in the ear, promoting repercussions on neurological reflexes, neurotransmitters, cytokines, immune system, and inflammatory processes ${ }^{37}$. According to a review ${ }^{37}$, the technique has good results in pain control in different situations; however, analgesia after operative procedures still has a controversial effect. This data corroborates the study by Kwan and $\mathrm{Li}^{14}$ that argues that vaginal birth with episiotomy can be considered a type of surgical intervention. Regarding acupuncture, one study ${ }^{25}$ used the wrist-ankle region to treat perineal pain after vaginal birth with episiotomy, and the results were significant. The stimuli were performed in region 1 of the right ankle, local to pain located in the lower part of the body. The study presented a significant result in the reduction of perineal pain assessed through the reduction of oral analgesic use. Despite the positive result, the study did not present quantitative data on pain in the perineal region, the primary outcome of the study. The use of analgesic during the puerperal period may be associated with other complaints such as uterine or breast pain. Thus, although the study presents good results, it is prudent to perform further studies analyzing the effect of the technique on perineal pain.

\section{CONCLUSION}

Several non-pharmacological analgesic resources/methods used in postpartum woman care in the immediate postpartum period were assessed in this systematic review. Of these, only TENS and cryotherapy presented well-established data regarding the significant effect on the reduction of abdominal/pelvic pain in postpartum women.

\section{REFERENCES}

1. Woods AB, Crist B, Kowalewski S, Carroll J, Warren J, Robertson J. A cross-sectional analysis of the effect of patient-controlled epidural analgesia versus patient controlled analgesia on postcesarean pain and breastfeeding. J Obstet Gynecol Neonatal Nurs. 2012;41(3):339-46.

2. Mathias AE, Pitangui AC, Vasconcelos AM, Silva SS, Rodrigues PS, Dias TG. Perineal pain measurement in the immediate vaginal postpartum period. Rev Dor. 2015;16(4):267-71

3. Mascarello KC, Matijasevich A, Santos ID, Silveira MF. Early and late puerperal complications associated with the mode of delivery in a cohort in Brazil. Rev Bras Epidemiol. 2018;21:e180010. [English, Portuguese; Abstract available in Portuguese from the publisher].

4. Cardoso PO, Alberti LR, Petroianu A. [Neonatal and maternal morbidity related to the type of delivery]. Cien Saude Colet. 2010;15(2):427-35.

5. Kainu JP, Sarvela J, Tiippana E, Halmesmäki E, Korttila KT. Persistent pain after caesarean section and vaginal birth: a cohort study. Int J Obstet Anesth. 2010;19(1):4-9.

6. Christianson LM, Bovbjerg VE, McDavitt EC, Hullfish KL. Risk factors for perineal injury during delivery. Am J Obstet Gynecol. 2003;189(1):255-60.

7. Çitak Karakaya I, Yüksel I, Akbayrak T, Demirtürk F, Karakaya MG, Ozyüncü Ö, et al. Effects of physiotherapy on pain and functional activities after cesarean delivery. Arch Gynecol Obstet. 2012;285(3):621-7.

8. Buhagiar L, Cassar OA, Brincat MP, Buttigieg GG, Inglott AS, Adami MZ, et al. Predictors of post-caesarean section pain and analgesic consumption. J Anaesthesiol Clin Pharmacol. 2011;27(2):185-91.
9. Abbaspoor Z, Akbari M, Najar S. Effect of foot and hand massage in post-cesarean section pain control: a randomized control trial. Pain Mang Nurs. 2014;15(1):132-6.

10. Steen M, Cooper K, Marchant P, Griffiths-Jones M, Walker J. A randomized controlled trial to compare the effectiveness of icepacks and Epifoam with cooling maternity gel pads at alleviating postnatal perineal trauma. Midwifery. 2000;16(1):48-55.

11. Verhagen AP, de Vet HC, de Bie RA, Kessels AG, Boers M, Bouter LM, et al. The Delph list: a criteria list for quality assessment of randomised clinical trials for conducting systematic reviews developed by Delphi consensus. J Clin Epidemiol. 1998;51(12):1235-41.

12. Moher D, Liberati A, Tetzlaff J, Altman DG. The PRISMA Group. principais iten para relatar revisóes sistemáticas e meta-análises: a recomendaçáo PRISMA. Epidemiol Serv Saúde. 2015;24(2):335-42.

13. Olsén MF, Elden H, Janson ED, Lilja H, Stener-Victorin E. A comparison of high- versus low-intensity, high-frequency transcutaneous electric nerve stimulation for painful postpartum uterine contractions. Acta Obstet Gynecol Scand. 2007;86(3):310-4.

14. Kwan WS, Li WW. Effect of ear acupressure on acute postpartum perineal pain: a randomised controlled study. J Clin Nurs. 2014;23(7-8):1153-64.

15. Lu YY, Su ML, Gau ML, Lin KC, Au HK. The efficacy of cold-gel packing for relieving episiotomy pain - a quasi-randomised control trial. Contemp Nurse. 2015;50(1):26-35.

16. Oliveira SM, Silva FM, Riesco ML, Latorre Mdo R, Nobre MR. Comparison of application times for ice packs used to relieve perineal pain after normal birth: a randomised clinical trial. J Clin Nurs. 2012;21(23-24)3382-91.

17. Leventhal LC, de Oliveira SM, Nobre MR, da Silva FM. Perineal analgesia with an ice pack after spontaneous vaginal birth: a randomized controlled trial. J Midwifery Womens Health. 2011;56(2):141-6.

18. Morais I, Lemos A, Katz L, Melo LF, Maciel MM, Amorim MM. Perineal pain management with cryotherapy after vaginal delivery: a randomized clinical trial. Rev Bras Ginecol Obst. 2016;38(7):325-32.

19. Kayman-Kose S, Arioz DT, Toktas H, Koken G, Kanat-Pektas M, Kose M, et al. Transcutaneous electrical nerve stimulation (TENS) for pain control after vaginal delivery and cesarean section. J Matern Fetal Neonatal Med. 2014;27(15):1572-5.

20. Pitangui AC, Araújo RC, Bezerra MJ, Ribeiro CO, Nakano AM. Low and high-frequency TENS in post-episiotomy pain relief: a randomized, double-blind clinical trial. Braz J Phys Ther. 2014;18(1):72-8.

21. Pitangui AC, de Sousa L, Gomes FA, Ferreira CH, Nakano AM. High-frequency TENS in post-episiotomy pain relief in primiparous puerpere: A randomized, controlled trial. J Obstet Gynaecol Res. 2012;38(7):980-7.

22. Lima, LE, Lima AS, Rocha CM, dos Santos GM, Bezerra AJ, Hazime AF, et al. High and low frequency transcutaneous electrical nerve stimulation in post-cesarean pain intensity. Fisioter Pesqui. 2014;21(3):243-8.

23. Santos JdeO, de Oliveira SM, da Silva FM, Nobre MR, Osava RH, Riesco ML. Low-level laser therapy for pain relief after episiotomy: a double-blind randomised clinical trial. J Clin Nurs. 2012;21(23-24):3513-22.

24. Santos JdeO, Oliveira SM, Nobre MR, Aranha AC, Alvarenga MB. A randomised clinical trial of the effect of low-level laser therapy for perineal pain and healing after episiotomy: A pilot study. Midwifery. 2012;28(5):e653-9.

25. Marra C, Pozzi I, Ceppi L, Sicuri M, Veneziano F, Regalia AL. Wrist-ankle acupuncture as perineal pain relief after mediolateral episiotomy: a pilot study. J Altern Complement Med. 2011;17(3):239-41

26. Han JS, Chen XH, Sun SL, Xu XJ, Yuan Y, Yan SC, et al. Effect of low- and high-frequency TENS on Met-enkephalin-Arg-Phe and dynorphin A immunoreactivity in human lumbar CSF. Pain. 1991;47(33):295-8.

27. Melzack R, Wall PD. Pain mechanisms: a new theory. Science. 1965;150(3699):971-9.

28. Mello LF, Nóbrega LF, Lemos A. Estimulaçăo elétrica transcutânea no alívio da dor do trabalho de parto:revisão sistemática e meta-análise. Rev Bras Fisioter. 2011;15(3):175-84.

29. Platon B, Mannheimer C, Andréll P. Effects of high-frequency, high-intensity transcutaneous electrical nerve stimulation versus intravenous opioids for pain relief after gynecologic laparoscopic surgery: a randomized controlled study. Korean J Anesthesiol. 2018;71(2):149-56

30. Kymplová J, Navrátil L, Knízek J. Contribution of phototherapy to the treatment of episiotomies. J Clin Laser Med Surg. 2003;21(1):35-9.

31. Bertolini GR, Silva TS, Ciena AP, Trindade DL. Efeitos do laser de baixa potência sobre a dor e edema no trauma tendíneo de ratos. Rev Bras Med Esporte. 2008;14(4):362-6.

32. Chow RT, Johnson MI, Lopes-Martins RA, Bjordal JM. Efficacy of low-level laser therapy in the management of neck pain: a systematic review and meta-analysis of randomised, placebo and active-treatment controlled trials. Lancet. 2009;374(9705):1897-908.

33. Huang YY, Chen AC, Carroll JD, Hamblin MR. Biphasic dose response in low leve light therapy. Dose Response. 2009;7(4):358-83.

34. Knight KL. Cryotherapy in Sport Injury Management. Champaign: Human Kinetics 1995.

35. Malanga GA, Yan N, Stark J. Mechanisms and efficacy of heat and cold therapies for musculoskeletal injury. Postgrad Med. 2015;127(1):57-65.

36. Murakami M, Fox L, Dijkers MP. Ear Acupuncture for immediate pain relief-a systematic review and meta-analysis of randomized controlled trials. Pain Med. 2016;18(3):551-64.

37. Hou PW, Hsu HC, Lin YW, Tang NY, Cheng CY, Hsieh CL. The History, mechanism, and clinical application of auricular therapy in traditional Chinese medicine. Evid Based Complement Alternat Med. 2015;2015:495684 